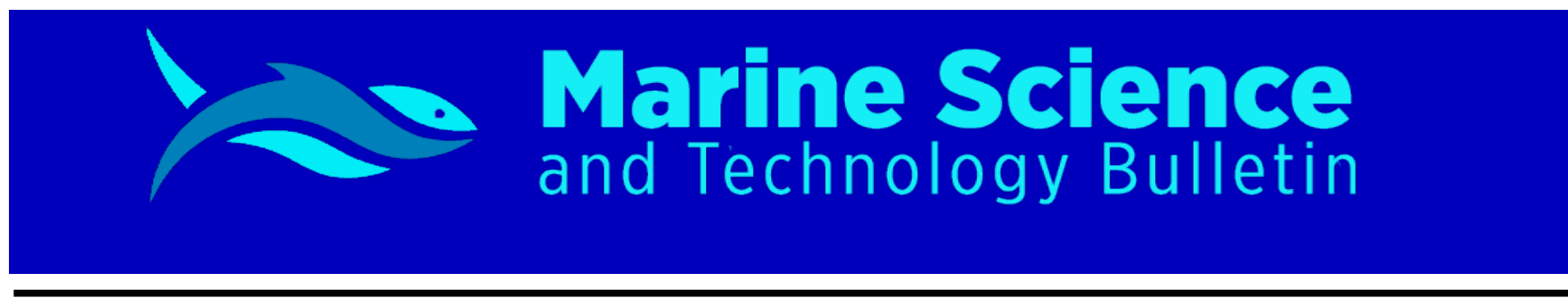

RESEARCH ARTICLE

\title{
The Behaviour of Turkish Bluefin Tuna (Thunnus thynnus) Fishing Fleet
}

\section{in the Mediterranean Sea}

\author{
Esin Yalçın ${ }^{1^{*}}$ \\ ${ }^{1}$ Mersin University, Maritime Vocational School, Mersin, Turkey
}

\section{ARTICLE INFO}

Article History:

Received: 31.10.2019

Received in revised form: 24.11.2019

Accepted: 25.11.2019

Available online: 27.11.2019

Keywords:

Bluefin tuna

Thunnus thynnus

Fishing fleet behaviour

GIS

EEZ

\begin{abstract}
A B S T R A C T
The main purpose of this study is to contribute to Turkish tuna fishing fleet management. In this context; The Turkish Bluefin Tuna (Thunnus thynnus Linnaeus, 1785) fishing fleet in our territorial waters and international waters in the Eastern Mediterranean were monitored on a spatio-temporal basis and a continuous monitoring model for BFT stock was established. Archival data sets of Bluefin Tuna (BFT) 2010-2016 spatial-temporal migration and remote sensing data sets of traces of fishing vessels and environmental factors (SST and Chl- $a$ ) were included in the model. Statistical analysis of the model was performed using Geographical Information System (GIS) based-approach and the results were presented on thematic maps. On the other hand, the importance of the announcement of The Exclusive Economic Zone (EEZ) for BFT fishing in Eastern Mediterranean was addressed in the study. Accordingly, the possibility of 'Turkey's Exclusive Economic Zone' announcement in Mediterranean Sea and its borders were discussed.
\end{abstract}

Please cite this paper as follows:

Yalçın, E. (2019). The Behaviour of Turkish Bluefin Tuna (Thunnus thynnus) Fishing Fleet in the Mediterranean Sea. Marine Science and Technology Bulletin, 8(2): 64-68.

\section{Introduction}

The main large pelagic fishes commercially exploited in the Mediterranean Atlantic Bluefin Tuna (Thunnus thynnus Linnaeus, 1785) (Perciformes: Scombridae). Bluefin Tuna (BFT) fishing has been the subject of the international law and the European Union (EU) law. Turkey became a member of the International Commission for the Conservation of Atlantic Tunas (ICCAT) in 2003 and currently continues BFT fishing with quotas in the framework of ICCAT rules. Within the scope of the ICCAT quota limitation, they are caught in our territorial and international waters in the Mediterranean, are farming of wild-caught fishes, and exported to the Japanese market when they reach the sufficient size.

The current fishing pattern in the Mediterranean Sea is the result of a long history of exploitation of marine resources that started several thousands of years ago (Farrugio et al., 1993). The fishing has been performed in the eastern Mediterranean since at least the $7^{\text {th }}$ millennium BC (Desse and Desse-Berset, 1994; Damalas and Megalofonou, 2012). Aristotle in his work History of Animals written in $350 \mathrm{BC}$ explained the migratory and reproductive habits of BFT in

\footnotetext{
* Corresponding author

E-mail address: esin.yalcin@mersin.edu.tr (E. Yalçın)
} 
the Aegean and Black Sea (D’Arcy Wentworth Thompson, 1910; Damalas and Megalofonou, 2012). Turkey is a peninsula surrounded by sea on three sides with a total of $8333 \mathrm{~km}$ of coastal line and BFT fishing in Anatolia dates back to ancient times (Karakulak, 2007). BFT is also a highly migratory species that seems to display a homing behaviour and spawning site fidelity in both the Mediterranean Sea and Gulf of Mexico (Figure 1) (Fromentin and Powers, 2005; Karakulak and Yıldız, 2016).

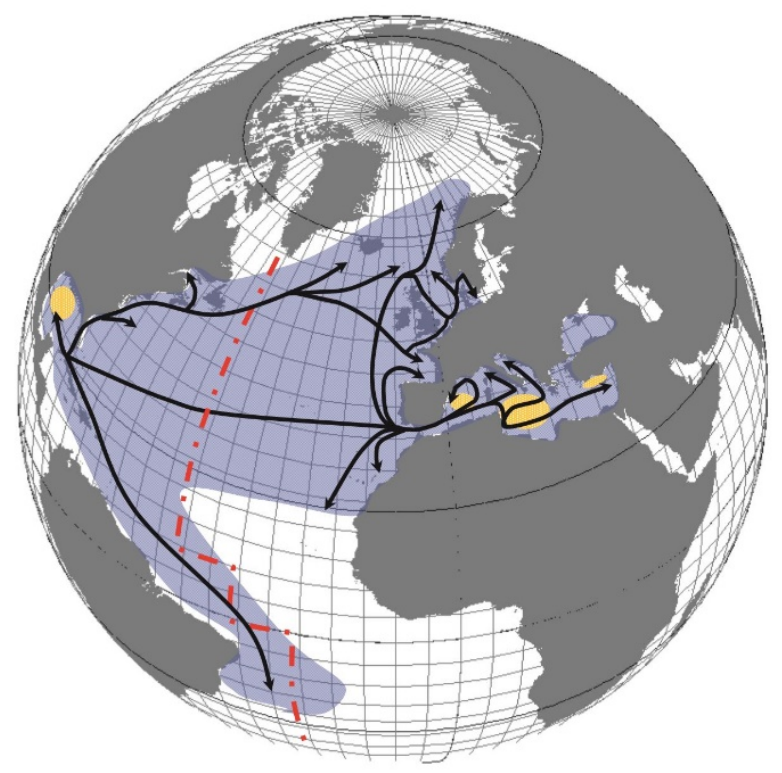

Figure 1. Map of the spatial distribution of BFT (blue), main migration routes (black arrows) and main spawning grounds (yellow areas) (Fromentin and Powers, 2005; Karakulak and Yıldı, 2016)

Temperature triggers spawning and determines the presence of BFT and due to their migration behaviour; distribution is significantly affected by spatial and temporal variations of environmental parameters. During their seasonal migrations, they follow changes in water temperature and currents, foraging along strong thermal fronts (Block and Stevens, 2001; Schick et al., 2004; Royer et al., 2004; Damalas and Megalofonou, 2012). Probability of encountering a school peaked in late spring months, eastwards at water temperatures above $22^{\circ} \mathrm{C}$ and around the full moon. It is known that BFT's tendency to migrate across borders due to its own biological characteristics is affected by environmental variables and it prefers areas with high chlorophyll-a (Chl- $a$ ) concentration for feeding and lowest Sea Surface Temperature (SST) value for spawning (Druon et al., 2011). It was reported that they tend to spend more than $50 \%$ of their time in ambient temperatures of 15 to $23^{\circ} \mathrm{C}$ (Wilson et al., 2005) and 14 to 26 ${ }^{\circ} \mathrm{C}$ in autumn and from 18 to $24^{\circ} \mathrm{C}$ in winter (Stokesbury et al., 2004). BFT can sustain cold (down to $3^{\circ} \mathrm{C}$ ) as well as warm (up to $30^{\circ} \mathrm{C}$ ) temperatures, while maintaining stable internal body temperature (Block et al., 2001; Karakulak and Yıldız, 2016). On the other hand, mesotrophic conditions, moderate and low Chl- $a$ content were determined in the range of $\sim 0.05$ to $0.15 \mathrm{mg} \mathrm{m}^{-3}$ (Druon, 2009). Finally, BFT distribution is significantly affected by spatio-temporal variations of environmental conditions (Fromentin et al., 2014). Mediterranean Sea is the primary spawning and fishing area for the BFT and one of these critical areas has been reported to be the Northeast Mediterranean (Karakulak et. al., 2004; Karakulak and Oray, 2009).

Spatio-temporal analysis by Geographical Information System (GIS) technology provides the tools to model species-habitat relationships and their variability and identify essential habitat areas. Overviews of predictive habitat modelling approaches have been presented for various species in Mediterranean Sea (Valavanis et al., 2004; Valavanis et al., 2005; Valavanis et al., 2008).

Monitoring, control and surveillance (MCS) activities of fishing fleet at the national and international level are of national concept, but it is also one of the key activities especially within the scope of management and regulation of fish stocks that have wide areas and migrate in between and across the territorial waters of countries. Due to the lack of scientific knowledge, it is difficult to evaluate the stocks in nature and in this context; scientific studies should be completed for sustainable management. There are international efforts and decisions in stock sharing in order to prevent the destruction of fish stocks, which are significant economically, and are decreasing in Mediterranean Sea. In this context, countries' need reliable data archives and numerical values obtained from analysis results based on scientific studies. In countries lacking scientific studies on the subject, it is inevitable to experience problems regarding fish stock sharing, especially in international regulations. Fields of competence are of pivotal importance for international commissions covering the Mediterranean. The main ones are International Commission for the Scientific Exploration of the Mediterranean (CIESM) created in 1916, the General Fisheries Council for the Mediterranean (GFCM) created in 1949 by The Food and Agriculture Organization (FAO), and the ICCAT in 1966. ICCAT developed a management plan until 2022 after the decline in BFT stocks as a result of overfishing activities in 2002, decided to apply a fishing quota to stakeholder countries and started fishing and cage fattening activities under its control (ICCAT, 2013). Turkey became a member of ICCAT in 2003. Before 2003 when the membership was started, Turkey participated in meetings as an observer and other countries benefited from BFT quota share jointly with some Mediterranean countries. Following the membership, as a result of the initiatives made with ICCAT, a special BFT fishing quota has been allocated to our country since 2004. Pilot study of the quota implementation began in our country; Turkey's quota in 2010 was determined to be 419 tons. Over the years, the success of the application was reflected on the ICCAT reports and quota of Turkey for 2019 is determined as 1880 tons, and 2305 tons for the year 2020 (ICCAT, 2018).

The legal and juristic arrangements related to the issue in order to place BFT fisheries on a legal basis at international level are included in both international law (under ICCAT precautions) and European Union (EU) laws. EU is legally obliged to submit precautionary approaches with scientific evidence and take preventive actions to protect the BFT. On 25 October 2010, the legal requirements for the protection of BFT were discussed at the legislative information meeting under EU law. According to the legal requirements discussed at the meeting, it was stated that the action plans prepared in accordance with the decisions adopted by ICCAT in 2010 to protect the BFT stocks must be realized and thus the Maximum Sustainable Yield (MSY) must be obtained until 2022 (ICCAT, 2013). According 
to the figures in the Standing Committee on Research and Statistics (SCRS) 2010 report under the Marine Strategy Framework Directive (MSFD; 2008/56/EC) developed by the EU due to the uncertain and critical situations of BFT in the East Atlantic and Mediterranean; member states are obliged to take the necessary measures to improve or protect their current environmental situation in order to maintain sustainable levels. With respect to BFT, all member states that own Sustainable Stock Biomass associated with Maximum Sustainable Yield (SSBMSY) or have stock on the stock biomass for up to 2020, according to the MSFD requirements, must guarantee and protect the EEZ in which BFT is are required. Each Member State is responsible for extending the EEZ border to the outmost maritime border as possible. Member states are obliged to have SSBMSY of all species in their waters, including BFT, by 2020, and to ensure healthy population distribution with little or no risk of compromising the genetic diversity of the stock.

\section{Material and Methods}

The study area covers Levant (Division 37.3.2) under FAO Major Fishing Area 37 and geographical areas coded 24 (North Levant), 25 (Cyprus Island) and 27 (Eastern Levant Sea) under GFCM geographical sub areas (GSAs). Within the framework of ICCAT rules, BFT fleet is tracked via satellite with Vessel Monitoring Systems (VMS) and automatic data recording is performed. However, VMS data is not legally available for use. For this reason, the data sets for the tracking of the fishing vessels used in the study were obtained through the Automatic Identification System (AIS) with the permission of the relevant ministry. AIS is a hardware and software system that allows the identification and positioning of marine vessels in marine traffic to be monitored automatically by providing almost real-time information flow from vessels. All fishing vessels, which have full length of $15 \mathrm{~m}$ and over, in Turkey tripping to a port and / or sequential ports have been equipped with AIS Class-B CS tool. All vessels in the BFT fleet are over $15 \mathrm{~m}$ long and AIS devices are available.

The archival records of each fishing vessel track and fishing marks indicated on the satellite navigation map of the vessels were obtained within the scope of the Turkish fishing vessel captains' volunteerism principle. Since dataset of the present study was derived from a fishing fleet-dependent survey, it was limited only to the fishing period (between $25^{\text {th }}$ May and $25^{\text {th }}$ June) within the scope of the ICCAT quota limitation. Fishing fleet was monitored by AIS (in coverage area) on a spatio-temporal basis and a total of 424 (present/absent) operating marks were obtained from 32 Turkish BFT fishing vessels from 2010 to 2016 .

Surface variables raw data (SST and Chl- $a$ ) were used at a daily and nighttime scale from the Moderate resolution Imaging Spectroradiometer/Aqua (MODIS/Aqua) ocean color sensor (https://modis.gsfc.nasa.gov/). Real-time images were obtained by rendering with The SeaWiFS Data Analysis System (SeaDAS) algorithm (https://seadas.gsfc.nasa.gov/) and finally mapped in ArcGIS 10.4.

Preferred GIS methods in the study allow the identification of unexpected relationships between multiple data sets and quantification of relationships for resource evaluation. Log normalization by statistical analysis was found to yield comparable definition of anomalies. In the study, ArcGIS Spatial Analyst Tools module, which is widely preferred in spatial-temporal data modelling is used. This module has a wide range of usage with powerful spatial modelling and analyses features such as mapping, cell-based raster data analysis, and interpolation of existing data in the database, querying multiple data between layers. In addition, Mapping Clusters analyses within the scope of Spatial Statistics Tools module were used in the study. To be a statistically significant hot spot, a feature must have a high value, surrounded by other features with high values as well. This tool identifies statistically significant spatial clusters of high values.

\section{Results and Discussion}

In the study, archive data sets of BFT's 2010-2016 spatial-temporal distribution and remote sensing data sets of environmental factors (SST and Chl-a) were included in the model and a continuous monitoring model of BFT stock was created with a GIS-based approach, then it was presented on thematic maps. Archival fishing coordinates of the model and accessible vessel traces (by AIS), BFT stock of probable fishing areas explored by fishing vessels and spatiotemporal migration path maps are submitted. Starting from May 25, BFT, coming from the south of Eastern Levant Sea and migrating to the Turkey's coasts at the north have been caught densely. Between $5^{\text {th }}$ and $20^{\text {th }}$ June when the temperature of air and sea rises, they migrate to the west between Turkey and TRNC and between $10^{\text {th }}$ and $25^{\text {th }}$ June they are mostly observed at the coasts of Turkey and caught mostly in Gulf of Antalya (Figure 2 and Figure 3).

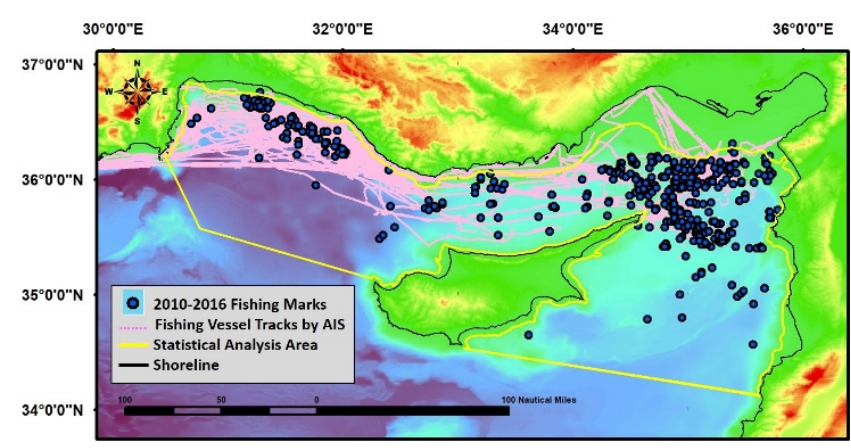

Figure 2. Archives fishing coordinates and fishing vessel tracks (by AIS) in the ArcGIS-based BFT stock continuous monitoring model

Composite maps of remote sensing archive data sets for SST and Chl- $a$, which are known to have significant impacts on BFT migration, suitable fishing area based on SST and suitable fishing area based on Chl- $a$ hot spot maps are submitted while this data is put to statistical analysis with fishery data sets (Figure 4 and Figure 5).

When the thematic maps are examined, the importance of the region in terms of BFT, which is one of the most valuable species of living marine resources, becomes obvious.

BFT fisheries in Turkey is one of the most strictly regulated and monitored fishing activity. Turkish BFT fleet is very active in Northeastern Mediterranean and continues to be profitable. Therefore, it is important to carry out proprietary activities in the seas, 
to observe the rights in the marine areas and to carry out such activities in accordance with the rules of international law.

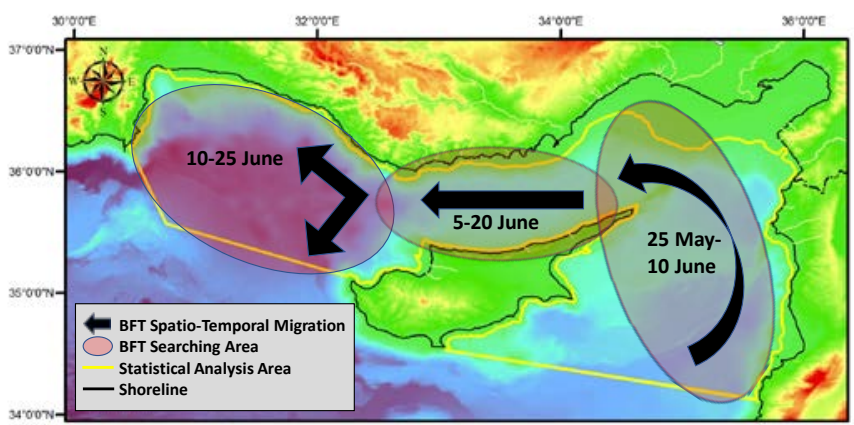

Figure 3. Spatio-temporal migration path of BFT stock in the Eastern Mediterranean and possible fishing areas explored by fishing vessels

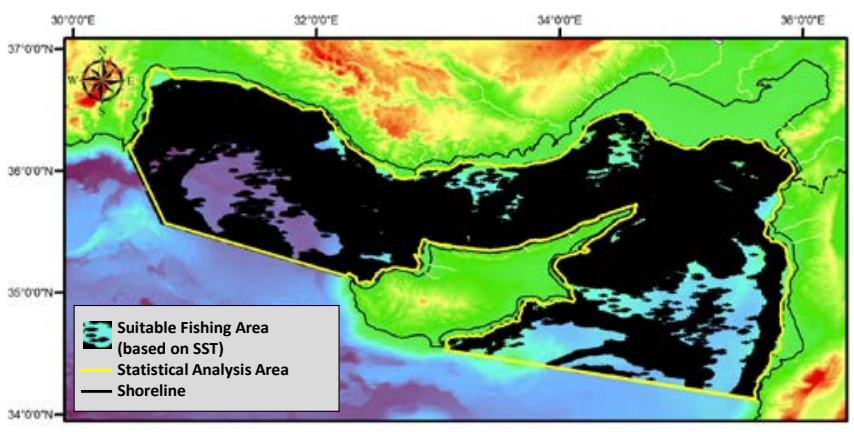

Figure 4. Statistical analysis results of suitable BFT fishing area based on SST

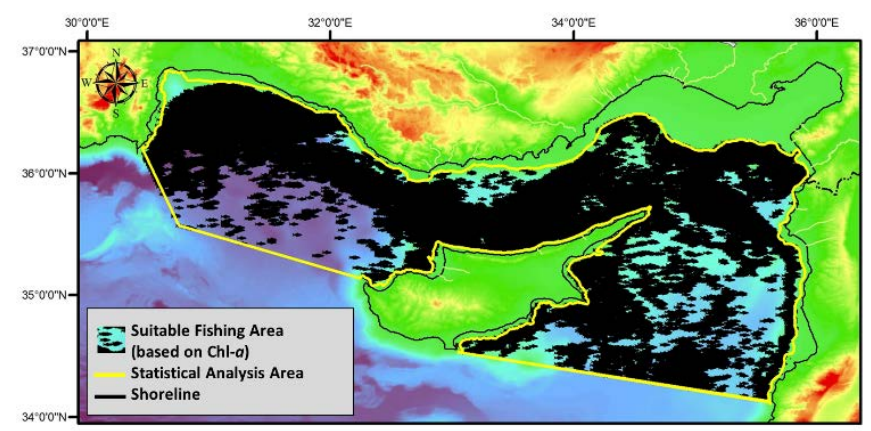

Figure 5. Statistical analysis results of suitable BFT fishing area based on Chl- $a$

Because spatio-temporal variability manages the definition of management units, stocks and boundaries, understanding the dynamics and spatio-temporal distribution of species is crucial for management (Fromentin and Powers, 2005). One way to accomplish such a task is by monitoring commercial BFT fleet, such as those undertaken here. Based on the relationships between environmental preferences and fisheries coordinates with time, an indirect determination of potential fishing area can be achieved. Therefore, current results may provide useful information for fisheries management authorities.

The extremely statistical significance of spatial determinants confirmed that BFT were not randomly received with the same probability; they tend to congregate in certain marine areas following a seasonal pattern. With a high probability of encountering a school increase to the Levantine, where the BFT mostly existed in spring and summer. This was reported argue that the surface water temperatures of the region contain a favorable spawning habitat in early May, as they reached the desired thresholds much earlier than other Mediterranean regions. Meanwhile the outcomes of this study supplement the recent study undertaken on the potential habitats of BFT, which suffered from a verification of estimates in the eastern Mediterranean region (Druon, 2010; Druon et al., 2011; Damalas and Megalofonou, 2012). Since dataset of the present study was derived from a fisherydependent survey, it was limited only to the fishing period (between $25^{\text {th }}$ May and $25^{\text {th }}$ June) within the scope of the ICCAT quota limitation. Inferences regarding of principal environmental effects on BFT spatio-temporal distribution and abundance in Northeastern Mediterranean region will be the main subject of next scientific paper.

On the other hand, although Turkey has been one of the active participants, they did not sign and approve 1982 United Nations Convention on the Law of the Sea (UNCLOS) text. The reason Turkey did not approve the agreement was not about the provisions concerning the protection of the marine environment; but mainly because of the regulations for the compulsory jurisdiction of the width of the territorial sea and maritime law disputes. In terms of international maritime law, fishing areas and their usage rights are of great importance. Turkey do not have an EEZ announcement yet in the Mediterranean, but it is likely that in the near future, there will be a boundary agreement between the coastal states in the Eastern Mediterranean, and the Turkish EEZ announcement will become obligatory. According to Article 61 of the United Nations Convention on the Law of the Sea (UNCLOS), under the heading of Conservation of the Living Resources; the coastal state has the exclusive right to determine the amount of living marine resources in EEZ, and shall determine the fishing capacity in its own EEZ. According to Article 62 under the heading Utilization of the Living Resources; the coastal state must aim to ensure the maximum exploitation of living resources, and will determine its ability to catch its own marine resources in EEZ.

Turkey should make an effort for protection and investigation of the marine environment, and most importantly, the operation of living resources in the Eastern Mediterranean. In addition, Turkey need to put forward strengths and weaknesses, develop new strategies and scientific projects, and urgently develop marine research policies and prepare action plans accordingly.

\section{Acknowledgments}

The presented study was carried out with the support of TUBITAK (No: 115O119). I would like to express my sincere respect and thanks to fishermen Captain İsmail MENEKŞE, Captain Ahmet MENEKŞE, Captain Erol BAYRAKTAR (Zamkinoz), Captain Sinan GİRİT, Ziya SERTER, Captain Mamuş YILMAZ, Captain Ergün ERYILMAZ, Captain Talat YAYLA, Captain İlyas TORLAK, Captain Yakup KURŞUN, Captain İbrahim SERTER, Captain Mahmut MENEKŞE, Captain Sertaç ÇINAROĞLU, Captain Orhan KARADENIZ, Captain Aytekin SERTER, Aktaşlar, Ağaoğulları, Tokerler, Türkmenler, Mamuliler, Geçiciler, Akgünler, Soydemirler, Kul Balıç̧ılık, Fat Balıç̧lık who significantly contributed to the study by sharing their knowledge and experience in the project meetings and workshops I have participated during the project, and all the precious captains of 
BFT fleets from past to present, to Mr. Abdullah DENIZER and Mr. Murat KUL for their support, and finally to Prof. Dr. Işık ORAY who also significantly contributed to the study with their remarks and suggestions.

\section{Conflict of Interest}

The author declares that there is no conflict of interest.

\section{References}

Block, B.A. \& Stevens, E.D. (2001). Tuna: Physiology, Ecology and Evolution, pp. 79-120. In: B.A. Block \& E. D. Stevens (eds.), Fish Physiology. San Diego: Academic Press.

Block, B.A., Dewar, H., Blackwell, S.B., Williams, T.D., Prince, E.D., Farwell, C.J., Boustany, A., Teo, S.L.H., Seitz, A., Walli, A. \& de Buen, F.D. (2001). Migratory movements, depth preferences, and thermal biology of Atlantic bluefin tuna. Science, 293: 1310- 1314.

Damalas, D. \& Megalofonou, P. (2012). Discovering where bluefin tuna, Thunnus thynnus, might go: using environmental and fishery data to map potential tuna habitat in the eastern Mediterranean Sea. Scientia Marina, 76(4): 691-704.

D’Arcy Wentworth Thompson, M.A. (translator). 1910. ARISTOTLE. The History of Animals (Historia Animalium). C.B. 12 v. illus. (1. 4) diagrs. (v. 5-6) $23 \mathrm{~cm}$. Clarendon Press Oxford. Available from: http://etext.virginia.edu/toc/modeng/public/ AriHian.html

Desse, J. \& Desse-Berset, N. (1994). Strategies de peche au 8ème millenaire: les poisons de Cap Andreas Kastros (Chypre). In: A. Le Brun (ed.), Fouilles recentes a Khirokitia Editions Recherche sur Civilisations, Paris, pp. 335-360.

Druon, J.N. (2009). Environmental Analysis of Bluefin Tuna: Identifying its Preferred Habitat in the Mediterranean Sea, EUR - JRC Scientific and Technical Research Reports.

Druon, J.N. (2010). Habitat mapping of the Atlantic bluefin tuna derived from satellite data: its potential as a tool for the sustainable management of pelagic fisheries. Marine Policy, 34: 293-297.

Druon, J.N., Fromentin, J.M., Aulanier, F. \& Heikkonen, J. (2011). Potential feeding and spawning habitats of Atlantic bluefin tuna in the Mediterranean Sea. Marine Ecology Progress Series, 439: 223-240.

Farrugio, H., Oliver, P. \& Biagi, F. (1993). An overview of the history, knowledge, recent and future research trends in the Mediterranean fisheries. Scientia Marina, 57: 105-119.

Fromentin, J.M. \& Powers, P.E. (2005). Atlantic bluefin tuna: population dynamics, ecology, fisheries and management. Fish and Fisheries, 6: 281-306.

Fromentin, J.M., Reygondeau, G., Bonhommeau, S. \& Beaugrand, G. (2014). Oceanographic changes and exploitation drive the spatio-temporal dynamics of Atlantic bluefin tuna (Thunnus thynnus). Fisheries Oceanography, 23(2): 147-156.

ICCAT, (2013). Annual Meeting, Recommendation 13-07; Recommendation by ICCAT amending the recommendation $12-03$ by ICCAT to establish a multi- annual recovery plan for bluefin tuna in the Eastern Atlantic and Mediterranean, 31pp.

ICCAT, (2018). Recommendation by ICCAT Establishing a MultiAnnual Management Plan for Bluefin Tuna in The Eastern Atlantic and The Mediterranean Sea. Retrieved in September 9, 2019 from https://www.iccat.int/Documents/Recs/ compendiopdf-e/2018-02-e.pdf

Karakulak, F.S. (2007). Catch and Effort Data of the Turkish Bluefin Tuna Fishery (2002-2005). Collective Volume of Scientific Papers, ICCAT, 60(3): 906-912.

Karakulak, S.F., Oray, I., Corriero, A., Aprea, A., Spedicato, D., Zubani, D., Santamaria, N. \& De Metrio, G. (2004). First Information on the Reproductive Biology of the Bluefin tuna (Thunnus thynnus) in the Eastern Mediterranean. Collective Volume of Scientific Papers, ICCAT, 56: 1158-1162.

Karakulak, S.F. \& Oray, I. (2009). Remarks on the fluctuation of the bluefin tuna catches in Turkish waters. Collective Volume of Scientific Papers ICCAT, 63: 153-160.

Karakulak, S.F. \& Yıldız, T. (2016). Atlantic Bluefin Tuna in the Mediterranean Sea: Fisheries, Farming, Management and Conservation, p. 320-332. In: Turan, C., Salihoğlu, B., Özbek, E.Ö., Öztürk, B. (eds.), The Turkish Part of The Mediterranean Sea Marine Biodiversity Fisheries Conservation and Governance. The Turkish Marine Research Foundation (TUDAV) Press, İstanbul. 595p.

Royer, F., Fromentin, J.M. \& Gaspar, P. (2004). The association between bluefin tuna schools and oceanic features in the Western Mediterranean Sea. Marine Ecology Progress Series, 269: 249-263.

Stokesbury, M.J.W., Teo, S.L.H., Seitz, A., O’Dor, R.K. \& Block, B.A (2004). Movement of Atlantic bluefin tuna (Thunnus thynnus) as determined by satellite tagging experiments initiated off New England. Canadian Journal of Fisheries and Aquatic Sciences, 61(10): 1976-1987.

Valavanis, V.D., Georgakarakos, S., Kapantagakis, A., Palialexis, A. \& Katara, I. (2004). A GIS environmental modelling approach to essential fish habitat designation. Ecological Modelling, 178: 417-427.

Valavanis, V.D., Pierce G.J., Zuur, A.F., Palialexis, A.S., Saveliev, A., Katara, I. \& Wang, J. (2008). Modelling of essential fish habitat based on remote sensing, spatial analysis and GIS. In Vasilis D. Valavanis (ed.), Essential Fish Habitat Mapping in the Mediterranean. Hydrobiologia, 612(1): 5-20.

Valavanis, V.D., Katara, I. \& Palialexis, A. (2005). Marine GIS: Identification of mesoscale oceanic thermal fronts. International Journal of Geographical Information Science, 19: 1131-1147.

Wilson, S.G., Lutcavage, M.E., Brill, R.W., Genovese, M.P., Cooper, A.B. \& Everly, A.W. (2005). Movements of bluefin tuna (Thunnus thynnus) in the northwestern Atlantic Ocean recorded by pop-up satellite archival tags, Marine Biology, 146(2): 409-423 